\title{
Project Work in Moroccan EFL Classroom: between the Official Guidelines' Recommendation and the Challenges of Implementation
}

\author{
Tariq BOUQETYB \\ Language, Communication, gender and educational engineering \\ Faculty of Letters and Human Sciences Dhar El Mehraz \\ Sidi Mohamed Ben Abdellah University \\ Fes, Morocco
}

Received: 8/10/2021

Accepted: 10/18/2021

Published:12/15/2021

\begin{abstract}
Project work is used in several educational settings, including foreign and second language teaching contexts. In the Moroccan English as a foreign language (EFL) classroom, the Moroccan Ministry of Education recommended implementing project work, and it is a common component of the Moroccan textbooks of English. Yet, there is a scarcity of studies conducted on the use of project work in Moroccan EFL classrooms. The main aim of the study is to investigate students' and teachers' attitudes towards project work. The study addresses the question about students' and teachers' attitudes towards project work and the factors behind those attitudes. It was conducted with sixty students and eight teachers belonging to two different high schools (Moulay Rachid and Abbas Sebti high schools) in Tangier. To collect data, the researcher made use of two data collection methods, namely the questionnaire and the interview. The results of the study showed that both students and teachers had positive attitudes towards project work. The results also revealed that not all teachers follow the steps of using project work. Based on the results, it was clear that the lack of technology is one of the most severe challenges that hamper the use of project work. The findings of this study could form the basis for further research and contribute to improving the learning and teaching situation in Moroccan high schools.

Keywords: challenges of project work, Moroccan EFL classroom, project work, teachers' and students' attitudes

Cite as: BOUQETYB, T. (2021). Project Work in Moroccan EFL Classroom: between the Official Guidelines' Recommendation and the Challenges of Implementation. Arab World English Journal, 12 (4) 462-475.
\end{abstract}

DOI: https://dx.doi.org/10.24093/awej/vol12no4.30 


\section{Introduction}

Based on the fact that learners gain knowledge or skills by experiencing and solving realworld problems, Project work is acknowledged to be effective and impactful in $21^{\text {st }}$-century education (Pham, 2018). It allows active involvement of students (Stoller, 2006) as it represents a transition from traditional teaching methods to student-centered education. As an essential component of task-based learning, which is probably the most widely adopted model of integrated language teaching (Sierra \& Ayala, 2019), project work is an effective way to integrate the four skills.

In the Moroccan EFL classroom, the Moroccan Ministry of Education recommended implementing project work (MEN, 2007). Project work is a common component of the Moroccan textbooks of English. After every two units, students work with their classmates on a project (Ticket to English, Gateway to English). However, it has been noticed that only a few teachers implement project work in their classrooms (this has been noticed based on my experience as a student and now as a public high school teacher of English for more than six years). Significantly, the present study is an unprecedented attempt to investigate this issue as no previous studies investigated the issue of project work in Moroccan EFL classrooms. The present study seeks to answer the following questions:

- What are the attitudes of both students and teachers towards the use of project work in English classes?

- What are the factors that may hinder teachers' implementation of project work in teaching?

In the Moroccan EFL context, the present study is an unprecedented attempt to investigate the attitudes of students and teachers towards project work. The study also aims at investigating the reasons behind the lack of use of project work in Moroccan EFL classrooms despite the Ministry's official guidelines recommendations.

\section{Literature review}

\section{Defining project work:}

Project work refers to a work that focuses on completing a task that involves a lot of resources, people and materials, and through which learners practice a range of skills and language systems (British Council, 2019). According to Stoller (2006), projects are contentbased activities in which learners are expected to do something with language. They are multiskill activities addressing topics or themes rather than specific language elements. Fried-Booth (2002) suggests that "projects are driven by the need to create an end-product" (p. 1). Such products can be an oral or written report, a poster, a handbook, a file, or a technology-based presentation.

Coming out with a product is an essential element in PW. Yet, the route to achieving this product is worthwhile, not the product itself (Fried-Booth, 2002). Learners in their journey of attaining an end-product can improve many aspects of their abilities and competencies. When working on projects, students "not only perform tasks they can cope with but also learn to work in a team, where it is important to listen to partners, agree or disagree with them, give arguments to support one's opinion" (Ludmila et al. 2015, p 177). Students may develop their language and research skills, critical thinking, creativity, autonomy, confidence, and collaboration skills. This 
leads us to claim that projects are both process and end-oriented (Stoller, 1997). Haines, (Year) refers to project work as "an approach to learning which complements mainstream methods and which can be used with almost all levels, ages and abilities of students" (as Cited in Carrol \& McCulloh, 2018, p. 108). Its main features are versatility and adaptability, and they account for the numerous types of projects identified by English language methodologists.

While reviewing the definition of PW, it's noticeable that other authors have defined PW with different voices. Given the variety of definitions, the present study adopts Katz's and Chard's definition (1992). They defined project work as "an extended study of a topic usually undertaken by a group of children, sometimes by a whole class, and occasionally by an individual child"(p, 4). Here, it's important to mention that Chard and Katz have perceived PW as a whole approach to teaching children, whereas in the present study PW is not as seen as an alternative to other teaching methods but a complementary element to mainstream methods of teaching different age groups.

\section{Types of project work}

A variety of types of project work are discussed in the literature. Projects could be classified into different types according to the degree of structure, the data collection techniques, sources of information, and the way through which information is reported.

The first main categorizing criterion of projects is the degree of structure in them. In this category, projects are divided into three main types. These are structured, semi-structured, and unstructured projects. Ke (2010) stated that structured projects are "determined, specified, and organized by the teacher in terms of topic, material, methodology, and production" (p.101). According to Stoller (2006), "details in semi-structured projects are determined in part by the teacher and in part by the learner" (p.21). In unstructured projects, students are independent in defining the directions and goals of the project (Stoller, 2006).

The second criterion is related to type of data collection techniques and sources of information. These include research projects, text projects, correspondence projects, survey projects, and encounter projects (Stoller, 2006). Research projects require the gathering of information through library research. Text projects are carried out by encountering with "texts" (e.g., literature, reports, news media, video and audio material, or computer-based data). As for correspondence projects, they necessitate communication with people to collect information using letters, faxes, phone calls, etc. Survey projects refers to the creation of a survey instrument, collecting and analyzing data from informants. Encounter projects result in face-to-face contact with guest speakers or individuals outside the classroom to collect the data.

Projects also differ in how information is reported. Stoller (2006) identified three types, namely production projects, performance projects, and organizational projects. Production projects are associated with the creation of bulletin board displays, letters, radio programs, poster sessions, written reports, photo essays, letters, handbooks, brochures, banquet menus, travel itineraries, and so forth. Performance projects could be staged debates, oral presentations, theatrical performances, or fashion shows. Organizational projects involve the planning and formation of a club, conversation table, or conversation partner program. 
In sum, Project work appears to be compatible with all learning styles, and it caters to students' differences. It provides students with different resources for the data collection and tools for presenting their final products. In this way, students could use resources and tools that are "appropriate to their levels and compatible with their technology knowledge" (Bell, 2010, p. 42).

\section{Project work and Second/Foreign Language Learning}

Project work was introduced into the field of English language teaching as a reflection of the principles of student-centered teaching (Beckett and Slater, 2005). The term project in the EFL context was first introduced by Freid-Booth (1986). In the EFL context, PW is believed to improve language skills. For example, Tassema (2005) contended that a classroom project is an excellent way to stimulate students' motivation to write because it offers the opportunity to match tasks with exciting topics that are relevant to the students. McCarthy (2010) reported that project work could be used as an effective tool to develop students' public speaking since students often present their products orally in front of the whole class. More interestingly, Fragoulis (2009) conducted a study on the implementation of the project in EFL in Greek primary schools (case study), and reported that "Most cognitive, emotional and psychomotor aims of project work were achieved by the majority of students... most students showed an improvement in all four language skills. Their speaking and listening skills, in particular, had the greatest improvement" (p.116). Fried-Booth (2002) claimed that project work is expected to give opportunities for learners to practice the language as they interact with each other using the target language.

In the literature, however, there exist evident discrepancies between general education students and teachers' evaluations of project work and English as second language (ESL) teachers' and students' evaluations of project work (Beckett,2002). General education students' and teachers perceptions indicate that PW creates opportunities for in-depth learning and fosters student independence and problem-solving skills ( Hadim \& Esche, 2002; Eklöf, 2014; Levine, 2004), whereas English as Second Language students' and teachers' evaluations of project work show that it is mainly associated with providing opportunities of comprehensible input and integrated language teaching. For example, McCarthy (2010) conducted teacher-initiated classroom research (action research) to see the extent to which PW can promote students' autonomy. The findings indicated that many students were not enthusiastic about exercising autonomy and were willing to work at only minimal level for the class credit, "they were generally unsure about their ability to be autonomous and after being introduced to project-based learning, a learning style completely foreign to them, they seemed even more uncertain" (p.231). Similarly, Beckett (2002) reported that "students felt that project work prevented them from learning from the teacher and textbooks and from focusing on language skills" (p. 52). Beckett also reported that teachers felt a lack of student respect and noted a drop in student attendance.

In sum, research in general education showed that project work fosters management and analytical skills. Evidence supporting this claim in Second language settings has not been clearly supported. PW in the EFL context, on the other hand, is primarily associated with providing opportunities for integrated language teaching. 


\section{Project work and students' attitudes towards learning:}

Different studies have found out that students' attitude plays a significant role in the learning of foreign language. Students holding a "positive attitude are academically far more successful than students with a negative attitude" (Gardner ,1985 cited in Yavuz \& Duman, 2018, p 190). However, several studies have dealt with the effects of project work on students' attitudes. Bas (2011) carried out a study investigating the impacts of project work on students' attitudes towards the English course and students' academic achievement of $9^{\text {th }}$-grade students in Turkey. Bas made use of the pre-test/ post-test control group research. In terms of the attitude scale towards the English course, there was a significant difference between the experimental group and the control group. Students who were instructed by PW showed more positive attitudes towards the English lesson. These findings were confirmed by Wanchid \&Wattanasin (2015) in their investigation of the attitudes of students of Mongkut's University of Technology towards project work. The researchers stated that project work made students "feel more confident and relaxed, that project work made English more interesting, improved their computer skills and the four English skills" (p.586). In a different context, Koparan and Güven's (2014) findings are also compatible with the previous stated findings. These authors reported that was a significant difference between the experimental and the control groups, "the students who were educated by project-based learning had more positive attitudes towards statistics than those who were educated by the instruction based on student textbooks" (p.82).

\section{Method}

\section{Setting and participants:}

This study took place at two different high schools in Tangier, Morocco, during the second semester of the 2020- 2021 school year. The population of this study is students and teachers of English in Moulay Rachid and Abbas Sebti high schools. The sample of the study consists of 30 students from each high school and eight English teachers. The study group belongs to two different classroom levels, first Baccalaureate, and second Baccalaureate literary stream students. This population was chosen since it represents the category that has studied English in Moroccan public schools for more than two years. Random sampling is used to choose a representative sample of those students. This sampling technique was chosen because it is more objective, and it gives a chance to everyone to participate in the study.

\section{Instruments}

Given the purposes stated above, data were collected through the use of two main instruments: the questionnaire and the interview (semi-structured interview). Thus, the study is of a quantitative and qualitative nature.

\section{The questionnaire}

The researcher opted for the questionnaire for a number of reasons. First, questionnaires can be administered to large groups in different locations. In this way, much time and energy could be saved. Second, questionnaires offer the possibility of anonymity which few data collection methods can offer. This is very important because the absence of the researcher may encourage participants to respond to all questions, even the sensitive ones. Third, data obtained from the questionnaire are more standard and uniform since all respondents are provided with the same questions. 
The students' questionnaire consisted of nine closed-ended questions. Multiple choice questions and yes-no questions were the dominant questions in the questionnaire. The study used Likert scales to determine the extent to which students agree or disagree with the given statements. Teachers were also given questionnaires to fill in. The questionnaire included a variety of items such as Likert scales, multiple-choice questions, yes-no questions, and openended questions.

\section{The interview protocol}

As for the semi-structured interview, it was used for three main reasons. The first reason was to triangulate data obtained from the questionnaire. Second, semi-structured interviews are personalized and therefore permit in-depth information, free response, and flexibility that could not be obtained using other data collection procedures. Third, in second language acquisition, interviews are the frequently used method to collect data about covert variables such as attitudes and perceptions.

\section{Research Procedures}

\section{Data Collection Procedures}

The data of the questionnaire were collected during the second semester of the 2020-2021 school year. In the first week of April, questionnaires were administered to the teachers and the students. Students and teachers were asked to answer the given questions and identify the extent to which they agree or disagree with particular items.

Before distributing the questionnaires to students, permission was taken from their teachers and the high school staff. With the collaboration of teachers, the purpose of the study, the time limit and method of their valuable responses were explained to students. Clarifications and explanations were provided when needed. In the second week of the same month, three teachers were purposefully selected for an interview. The purpose of the interview was to gain in-depth information about how exactly teachers perceive the use of project work in their teaching and the obstacles they face when they implement it.

\section{Data analysis procedures}

The interview data were transcribed and analyzed using content analysis. These data from the interview responses were used to support the results of the questionnaire data, and to find out the types of obstacles that hinder teachers' use of project work.

The quantitative data of the questionnaire were analyzed using the Statistical Package of Social Sciences (SPSS version 18.0). Thus, the analysis of the quantitative data included some statistical techniques such as chi-square and frequency.

\section{Results}

This section reports the results of the study. It gives details about the two separate questionnaires that involved sixty students (60) and eight teachers, and the interview which was conducted with three teachers. 


\section{Presentation of students' questionnaires}

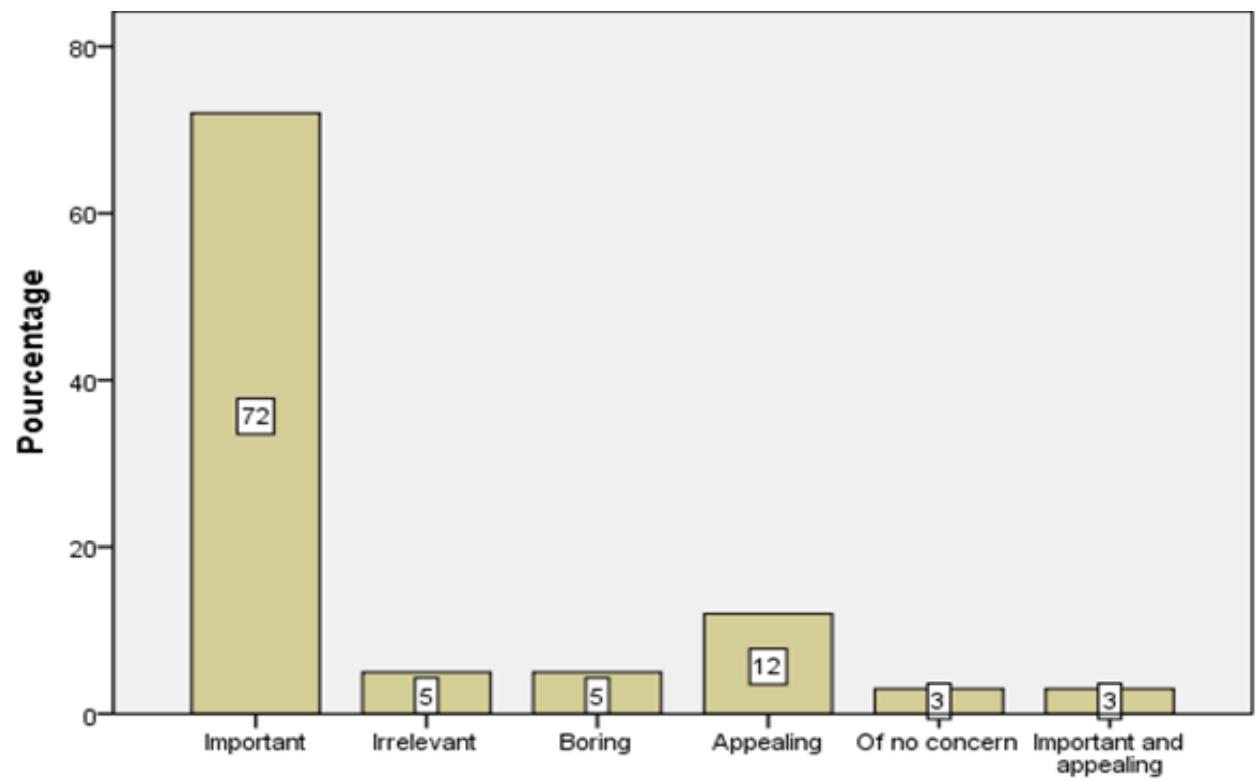

Figure 1. The Importance of project work

Figure one shows that majority of students $(72 \%)$ stated that project work is important. Figure two reveals the reasons behind that.

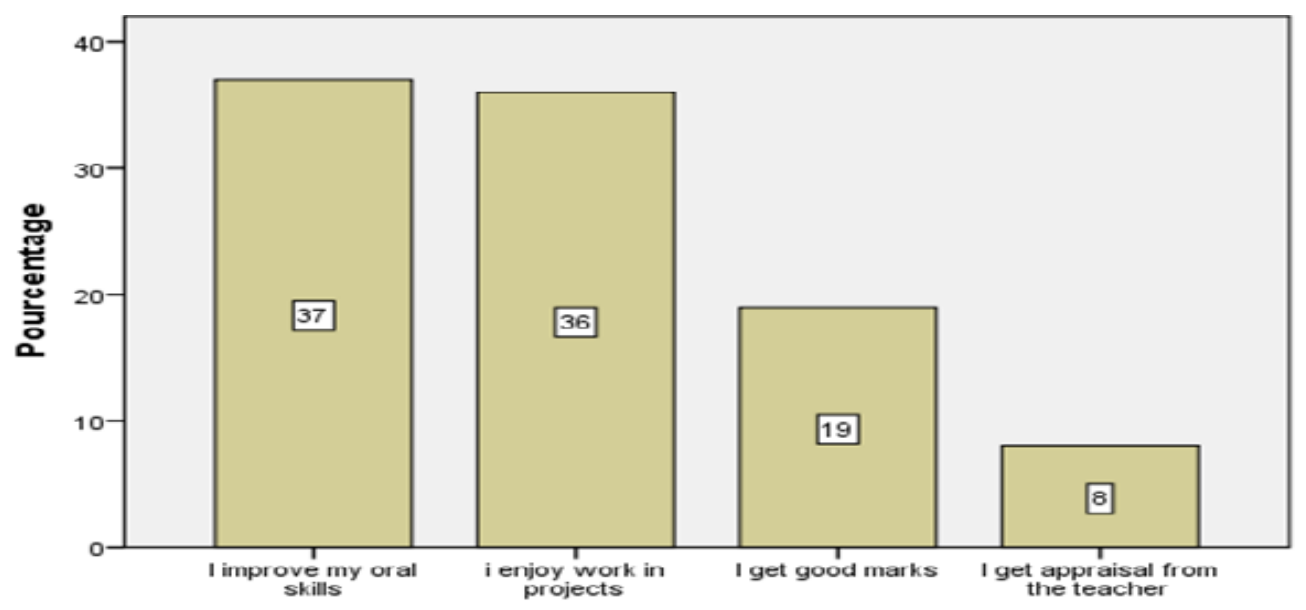

Figure 2.Reasons for preferring project work

When asked to give their reasons for preferring project work, a great number of students (37 0\%) stated that they want to "improve their oral skills" and they enjoy working in projects. $19 \%$ of them reported that they want to get good marks whereas few students want to get appraisal from the teacher. 
Table 1. project work and language skills

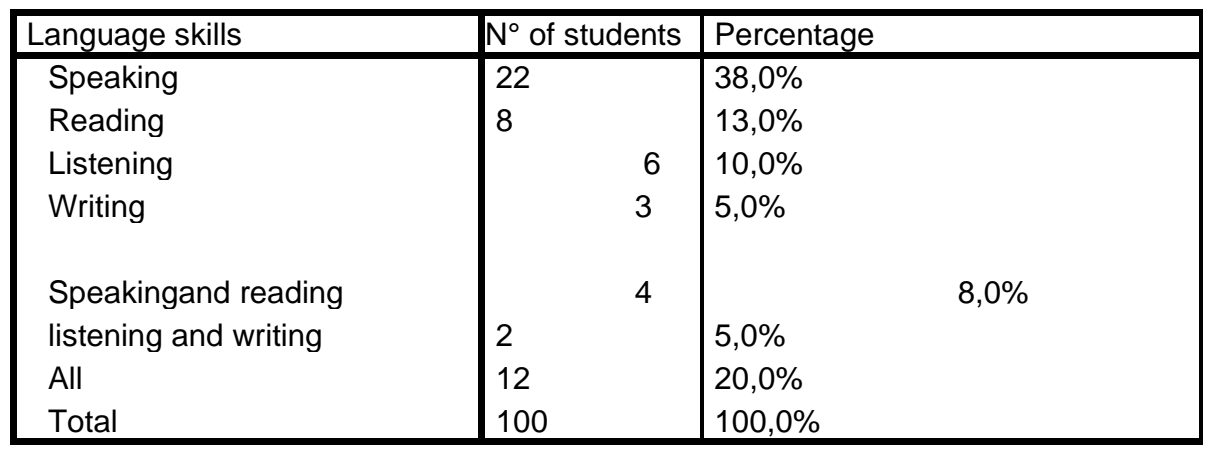

The above-stated results show that the majority of students believe that project work is important for speaking skills (38\%). This can be explained by the fact that students are required to present their projects orally, for example, in the form of a PowerPoint presentation. Some stated that it is important for all their language skills

\section{Presentation of Teachers' Questionnaires and Interviews}

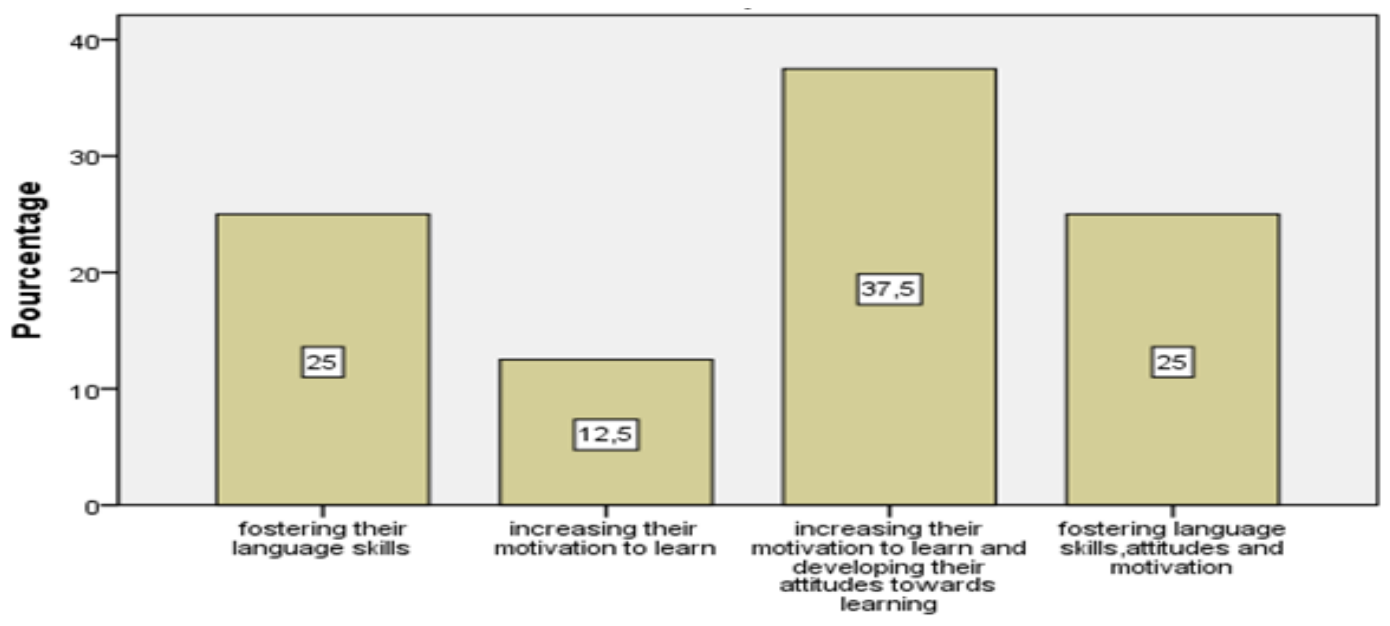

Figure 3: The importance of project work

Figure three reveals that $25 \%$ of teachers stated that project work fosters students' language skills. $12,5 \%$ of teachers see that it increases their motivation to learn. Thirty-seven percent of teachers declared that project work increases both students' motivation to learn and their attitudes towards learning. While $25 \%$ of them believed that it fosters students' language skills, attitudes and motivation.

When asked to state if they use project work and for what reasons, all interviewees agreed that they use project work. They stated a variety of reasons for such use. For example, respondent one said: "Yes, project work gives the opportunity to shy, weak, and slow students to develop their autonomy. I use it also to evaluate my students' competence. Tests are not enough to test students..." 
Others claimed that project work can be used as an effective tool to facilitate learning for students, for example, teacher two said, "Yes, I use project work to motivate students and facilitate learning for them. Many students are scared to speak in English. Project work helps these students to develop their personality and helps them to go beyond the classroom" she added" Another reason why I use project work is that it involves the four language skills". Teachers' three answer is approximately similar to teacher two. She responded to the question as follows: "In my point of view, project work helps students to be autonomous, more motivated, and acquire a number of skills such as critical thinking, research skills, and of course language skills."

Table 2. challenges of project work

\begin{tabular}{|l|l|l|}
\hline \multicolumn{2}{|c|}{ The factors that may hinder the use of project work } \\
\hline $\begin{array}{l}\text { Student- } \\
\text { related } \\
\text { factors }\end{array}$ & $\begin{array}{l}\text { School }- \\
\text { related } \\
\text { factors }\end{array}$ & $\begin{array}{l}\text { Extern } \\
\text { al } \\
\text { factors }\end{array}$ \\
\hline- & - lack of & - Time \\
Students & technolo & constra \\
linguisti & gy. & int. \\
c & -lack of & - \\
compete & enough & Numbe \\
nce & books & r of \\
-Lack of & and & student \\
desire. & magazin & s. \\
- & es in the & - \\
Students & school & Follow \\
status. & library. & ing the \\
social & & textboo \\
& & k. \\
\hline
\end{tabular}

Table two gives a summary about teachers' views about the possible challenges that hinder the implementation of project work. The data obtained from the interviews is categorized into the three main categories. To support this, teacher one said: "Some students belong to poor families; they do not have access to technology.... Some students are not interested... They do not show a desire to make efforts". In addition to the lack of technology access, teacher two stated that time constraints, the number of students, students' linguistic competence, and the necessity to follow the textbook are obstacles that hinder the use of project work. She said: "There are many obstacles. For example, time constraints, the number of students, and the linguistic competence of students. Also, we have to follow the textbook. School conditions are also a real challenge. There is no internet access... Libraries should be equipped with computers".

\section{Discussion}

The results of the study show that both teachers and students hold a positive attitude towards the use project work. They both think that is a good way to teach/ learn English. For the majority of students, project work is important for speaking skills. In this context, Stoller (2OO6) stated that all language skills are involved. For example, to collect data, students should make 
use of a variety of resources. They may read books and magazines. Also, they may conduct interviews with native speakers. To do that, students should be good listeners and good speakers. As stated earlier, students are required to present their products orally in front of the audience. Furthermore, the findings of the study are compatible with some other works that are previously mentioned in the review of the literature. For instance, Bas (2011)'s research carried out a study investigating the effects of project work on students' attitudes towards the English course and students' academic achievement of ninth-grade students in Turkey reveals that "PBL creates a positive and significant difference in both academic success and attitude" (Yavuz \& Duman, 2018. P190).

The findings of the study also demonstrate that the majority of students perceive project work as important. This contradicts the findings of Beckets' study (2002) that not all students in the EFL context prefer to work on projects. A considerable number of the respondents also stated that they use project as a way to motivate their students and foster their autonomy, unlike the case of McCarthy (2010), who conducted a teacher-initiated classroom research (action research) to see the extent to which PW can promote students' autonomy. Her findings indicated that many students were not enthusiastic about exercising autonomy and were willing to work at a minimal level for the class credit.

The findings of the study also state that there are a number of obstacles that hinder the use of project work. The low-linguistic competence of students, the time-consuming nature of project work, among others, are the most serious obstacles that hinder its use in the classroom. This can be substantiated by Krajcik et al. (1998), on their investigation of a project-based science; the authors stated that in-depth investigation of projects took longer time than expected and thus are time-consuming.

\section{Conclusion}

The purpose of this study was to investigate students' and teachers' attitudes towards project work in Moroccan EFL classrooms. Based on the findings of the study, some conclusions and recommendations can be derived. First, Teachers can use project work for a number of purposes. It has been proven to give students opportunities to develop their language skills as well as social skills. Project work can be also used to motivate students to learn. Second, the implementation of project work can be very challenging for teachers. Lack of technology, the low-linguistic competence of students, the time-consuming nature of project work, among others, are the most serious obstacles that hinder its use in the classroom. Teachers also lack any training in using project work. Therefore, it is recommended that they attend workshops and training sessions. Last, the findings of the study could form the basis for further research. Here, experimental research can be used to investigate the effects of project work for various subject areas in the Moroccan context.

\section{Limitations of the study}

This study is not without its limitations. The small size of participants and the very limited number of high schools investigated could affect the degree to which generalizations can be made. In addition, due to Covid-19's spread, the researcher couldn't include some observational techniques. Observing what goes on the classroom while using project work will give detailed account of how students interact and practice their roles within project work pedagogy. 


\section{About the author}

Tariq BOUQETYB is a teacher of English as a foreign Language in Moulay Rachid public high school in Tangier, Morocco. He is also a $\mathrm{PhD}$ candidate at Sidi Mohammed Ben Abdellah university, Faculty of Letters and Human Sciences, Dhar El Mehraz, Fes. His research interests include applied language studies, English language learning and teaching, and migrant education. ract and practice their roles within project work pedagogy. https://orcid.org/0000-0002-36012340

\section{References}

Baş, G. (2011). Investigating the effects of PBL on students academic achievement and attitudes towards English lesson. The Online Journal Of New Horizons In Education, 1(4), 115.Retrieved from http://www.tojned.net/pdf/tojnedv01i04-01.pdf

Beckett, G.H. (2002). Teacher and Student Evaluations of Project-Based Instruction.TESL Canada Journal, 19 (2), 52-66

Beckett, G.H., \& Slater, T. (2005). The Project Framework: a Tool for Language, Content, and Skills Integration. ELT Journal, 59 (2), 108-116. https://doi.org/10.18806/tesl.v19i2.929

Bell, S. (2010). Project-Based Learning for the $21^{\text {st }}$ century: Skills for the Future. The Clearing House, 83, 39- 43

British Council. 2019. Project Work. Retrieved from

https://www.teachingenglish.org.uk/article/project-work

Carrol, M, \& McCulloh M. (2018). Understanding Teaching and Learning in Primary Education $\left(2^{\text {nd }}\right.$ Ed). SAGE Publication

Duman, B., \& Özlem, K. (2018). The Effect of project-based learning on students' attitude towards English classes. Journal of Education and Training Studies. 6 (11). Doi 10.11114/jets.v6i11a.3816

Eklöf, A. (2014). Project Work, Independence and Critical Thinking. Department of Education, Communication and Learning. University of Gothenburg. Doctoral Thesis. 978-91-7346-7940 .

Esche, K., \& Hadim, A. (2002). Enhancing the Engineering Curriculum through Project-Based Learning. Conference Paper. Proceedings - Frontiers in Education Conference -DOI: 10.1109/FIE.2002.1158200

Fragoulis, I. (2009). Project-Based Learning in the Teaching of English as a Foreign Language in Greek Primary Schools: From Theory to Practice. English Language Teaching, 2 (3).

Fried-Booth, D (2002). Project work ( $2^{\text {nd }}$ Ed.).Oxford: Oxford University Press.

Gardner, R.C. et al. (1985). The Role of attitudes and motivation in second language learning: correlational and experimental considerations. Language Learning: a Journal of Research in Language Studies. 35 (2). //doi.org/10.1111/j.1467-1770.1985.tb01025.x

Jurany S., \& Francy, A. (2019). Integrating the Four Language Skills through Task-Based Learning with Second Grade Children at Liceo Patria School. Universidad Cooperativa de Colombia.

Katz, L. G., \& Chard, S. (1992). The Project Approach. Educational Resources Information Center (ERIC). Available at https://eric.ed.gov/?id=ed340518

Ke, L. (2010). Project-based College English: An Approach to teaching non-English Majors. Chinese Journal of Applied Linguistics (Bimonthly), 99-112

Koparan, T., \& Güven, B. (2014). The Effect on the 8th grade students' attitude towards statistics of project based learning. European Journal of Educational Research. 3 (2), 73-85. 
Krajcik et al. (1998). Inquiry in project-based science classrooms: Initial attempts by middle school students. Journal of the Learning Sciences, 3 (4). https://doi.org/10.1080/10508406.1998.9672057

Levine, S. (2004). Global Simulation: a Student-Centered, Task-Based Format for Intermediate Foreign Language Courses. Foreign Language Annals. 37 (1):26-36.

10.1111/j.1944-9720.2004.tb02170.x

Ludmila M., et al. (2015). Project-based Method in Teaching Foreign Language for Specific Purposes. Procedia - Social and Behavioral Sciences. 215,176 - 180

M.E.N. (2007). English language guidelines for secondary schools: Common core, first year, and second year baccalaureate. https://moroccoenglish.com/me-md/2017/07/92-pagesGUIDELINES-FOR-SECONDARY-SCHOOLS-All-Streams-and-Sections.pdf

McCarthy, T. (2010). Integrating project-based learning into a traditional skills-based curriculum to foster learner autonomy: An action research. The Journal of Kanda University of International Studies, 22, 221-244.

Stoller, F. (2006).Establishing a theoretical foundation for project-based learning in second and foreign language contexts. In G. H. Beckett, \& P. C. Miller (Eds.), Project-Based Second and Foreign Language education: past, present, and future (pp. 19-40). Greenwich, Connecticut: Information Age Publishing.

Stoller, F. (1997). Project work: a means to promote language content. English Teaching Forum. $35(4), 2-9$.

Tassema, K. A. (2005). Stimulating writing through project-based tasks. English Teaching Forum, 43(4). 22-28

Thuan, P. (2018). PROJECT-BASED LEARNING: FROM THEORY TO EFL CLASSROOM PRACTICE.. Conference Paper. Hoa Lu University, Vietnam.

Wanchid, R., \& Wattanasin, K. (2015). The Investigation of students' sttitudes toward project work in enhancing independent learning in english I at King Mongkut's University of Technology North Bangkok. Mediterranean Journal of Social Sciences. 6 (5).

\section{Appendices}

Appendix A

\section{Interview with Teachers}

1-Do you use project work in your teaching? Why/ why not? If yes, what benefits project work offer to your students?

2-How do usually your students respond to project work activities?

3-According to you, what are the obstacles that may hinder the use of project work in teaching English?

\section{Appendix B:}

\section{Students Questionnaire} You are kindly requested to fill in this questionnaire; the purpose is to identify students' perceptions of the use of project work in English. Please, read each question carefully and respond, as accurately and candidly as you can. Your participation is completely voluntary and will not influence your school grades. 


\section{SECTION I: Demographic information}
1) Gender:
Male:
2) Age: .....
3) Level of education:
a) Common core
b) First year baccalaureate
c) Second year baccalaureate
4) The name of the institution

Female:

5) Have you ever had a project work in class?

Yes $\square$

No

If yes, how many projects have you been involved in this year?

SECTION II:

Please tick as appropriate

1) Do you enjoy the English course?

Yes

No

If yes, which of these activities do you enjoy the most?

$\square$ Team-based research projects.

Playful activities

$\square$ Learning independently by reading.

Learning through listening to teacher' lectures.

Learning by hands-on experiences (learning by doing).

2) Does project work make you more motivated to participate in the English course activities?

Yes

No

If yes, to what extent?

Motivated

Very motivated

$\square$ Undecided

3) Identify how you feel about project work in your classes?

$\square$ Important

Appealing

$\square$ Irrelevant

Boring

Of no concern

\section{Section III}

Please indicate the extent to which you agree or disagree with the following statements

\begin{tabular}{|l|l|l|l|l|l|}
\hline & $\begin{array}{l}\text { Strongly } \\
\text { Agree }\end{array}$ & Agree & neutral & Disagree & $\begin{array}{l}\text { Strongly } \\
\text { Disagree }\end{array}$ \\
\hline $\begin{array}{l}\text { 1. I like it when the teacher assigns to us } \\
\text { projects to work on }\end{array}$ & & & & \\
\hline $\begin{array}{l}\text { 2. I believe that working in projects is the best } \\
\text { way to learn English. }\end{array}$ & & & & \\
\hline
\end{tabular}

ISSN: 2229-9327 


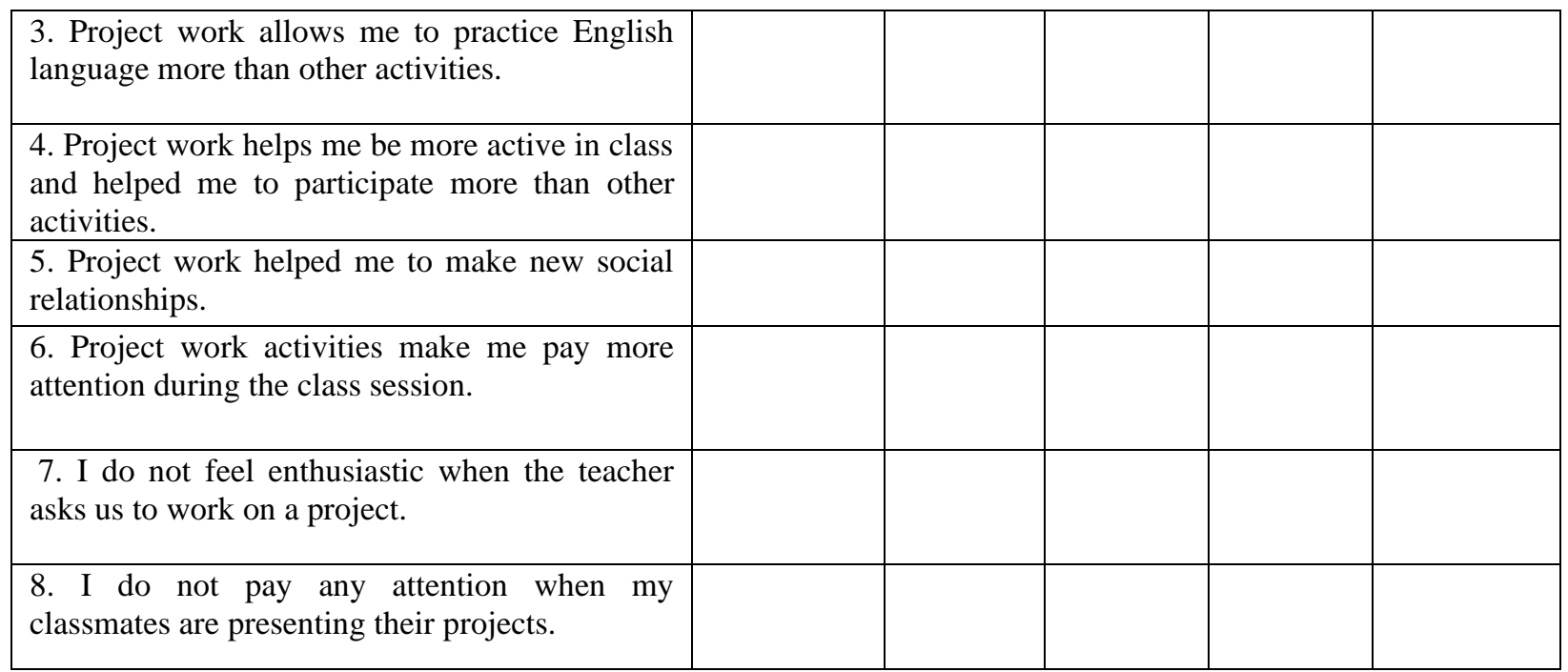

\section{SECTION IV}

\section{Please indicate as appropriate}

1) Do you like to work in projects?

Yes $\square$

No

If yes, can you indicate the reason why?

$\square$ I improve my oral skills

$\square$ I enjoy work in projects

I get good grades

I get appraisal from the teacher

2) If you are given the choice, how many projects you want to work on per year?

$\square 1$ project

$\square 2$ projects

$\square 3$ projects

$\square$ More

3) Project work allows me to become a good:

Speaker

Reader

Listener

Writer

Thank you for your time and for your highly appreciated contributions to this study 